This is the final draft of my paper "Kantian Non-Evidentialism and its German Antecedents: Crusius, Meier and Basedow". Kantian Review, 24(3), 359-384. doi:10.1017/S1369415419000177. Please cite the published version, which differs in the standard ways (formatting, pagination, small grammatical errors, etc.) from the draft.

\title{
Kantian Non-Evidentialism and its German Antecedents: Crusius, Meier and Basedow
}

\author{
BRIAN A. CHANCE \\ University of Oklahoma/Oklahoma School of Science and Mathematics \\ Email: brianchance@ou.edu
}

\begin{abstract}
This article aims to highlight the extent to which Kant's account of belief draws on the views of his contemporaries. Situating the non-evidentialist features of Crusius's account of belief within his broader account, I argue that they include antecedents to both Kant's distinction between pragmatic and moral belief and his conception of a postulate of pure practical reason. While moving us closer to Kant's arguments for the first postulate, however, both Crusius's and Meier's arguments for the immortality of the soul fail to anticipate the most important aspect of their Kantian counterparts. Developing the nonevidentialist features of Basedow's account of belief, I distinguish it from its Pascalian and Jamesian relatives and argue that it is the clearest antecedent to Kant's arguments for the first and second postulates. Finally, I consider the development of Kant's account of belief after the first Critique in light of the foregoing, and discuss the broader implications of my analysis.
\end{abstract}

Keywords: Crusius, Meier, Basedow, ethics of belief, Glaube, non-evidentialism, postulates of pure practical reason 
Kant's account of belief (Glaube) has received considerable attention in recent years. However, much of this work has ignored the ways in which Kant draws on the views of his contemporaries. ${ }^{1}$ While Chignell lauds Kantian belief as an alternative to the evidentialism of Descartes and Locke and an anticipation of the contemporary epistemic notion of acceptance, for example, he does little to bring Kant into dialogue with eighteenth-century philosophers (Chignell 2007a and 2007b). As a result, one would be forgiven for thinking that there are no non-evidentialist accounts of rational belief between Pascal and Kant and that the latter's views, including his arguments for the postulates of immortality and God's existence, develop largely in isolation from Kant's intellectual community.

My aim in this essay is to correct this record by drawing attention to the affinities between Kant's views and those of three of his contemporaries: C. A. Crusius (1715-75), G. F. Meier (1718-77) and J. B. Basedow (1724-90). Crusius develops a non-evidentialist account of belief that predates Kant's by nearly forty years and anticipates both his distinction between pragmatic and moral belief as well as the seemingly quintessential Kantian notion of a postulate of pure practical reason. Yet, while both Crusius and Meier articulate arguments for immortality that are moral in some sense, it is Basedow who first articulates a non-evidentialist justification for belief in the existence of God and immortality of the soul. Moreover, Basedow's account is distinct from its Pascalian and Jamesian relatives in providing a distinctly moral justification for belief; and as we will 
see, there is ample evidence that Kant understood the relevance of this account to his own arguments for the postulates.

In section 1, I briefly introduce Kant's account of belief in its initial, first Critique form. In section 2, I situate the non-evidentialist aspects of Crusius's account of belief within his broader account and argue (a) that what I shall call prudential and lawful beliefs are antecedents to Kantian practical and moral beliefs and (b) that Crusius's illustration of the latter anticipates Kant's notion of a postulate of pure practical reason. In section 3, I examine Crusius's and Meier's arguments for the immortality of the soul and argue (c) that both fail to anticipate the most original aspect of Kant's arguments for this claim. In section 4, I develop the non-evidentialist aspects of Basedow's account of belief and, in particular, his account of the duty to belief (Glaubenspflicht), and argue (d) that his arguments are the clearest antecedents to Kant's arguments for the first and second postulates. In section 5, I consider the development of Kant's account of belief subsequent to the first Critique in light of the results of the previous sections and discuss the broader implications of my analysis for our understanding of Kant and the development of non-evidentialist arguments.

\section{Kantian Pragmatic and Moral Belief}

For both Kant and the other philosophers we shall consider, the broad category under which belief falls is assent or holding-to-be-true. ${ }^{2}$ In Kant's parlance, belief is a form of assent that is both 'subjectively sufficient' and 'objectively insufficient' (A822/B850). ${ }^{3}$ Knowledge, by way of contrast, is a form of assent that is both subjectively and objectively sufficient, while opinion - the third and final form of assent Kant recognizes - is subjectively and objectively insufficient (A822/B850). ${ }^{4}$ Subjective sufficiency has 
both psychological and normative aspects. On the one hand, Kant's comments suggest it involves (a) a firm commitment to a proposition and (b) a strong sense of confidence in its truth (A827/B855). We are both reluctant to abandon propositions we believe and willing to act on the basis of their truth. Yet in distinguishing belief from opinion and also what he calls persuasion (Überredung), Kant also clearly holds that an assent qualifies as belief only if it has a sufficient warrant; and in order to distinguish belief from both opinion and knowledge, it is clear that these warrants must be non-epistemic in nature. $^{5}$

While the foregoing is largely uncontroversial, there is some question as to whether belief also involves what Kant calls conviction (Überzeugung). ${ }^{6}$ Conviction, as Kant initially introduces it, is an assent that is 'valid for everyone merely as long as he has reason', and is contrasted with persuasion, which Kant characterizes as an assent 'grounded only in the particular constitution of the subject' (A821/B849). Persuasion, which is a false assent (ein blosser Schein) that is held to be true, cannot be distinguished from conviction from the point of view of the subject, i.e. when 'the subject has taken something to be true merely as an appearance of his own mind'. Yet, in attempting to communicate the grounds of this assent to others, it is possible for a subject to make herself aware that a given assent is persuasion, not conviction. More importantly, however, the fact that conviction is 'valid for everyone merely as long as he has reason' also entails that the ground of assent is 'objectively sufficient'; and this in turn implies that only knowledge qualifies as conviction (A821/B849; cf. A822/B850).

Elsewhere, however, it appears that belief also involves conviction. At the close of his initial distinction between knowledge, opinion and belief, for example, Kant writes that 
'subjective sufficiency is called conviction (for myself)', while objective sufficiency is called 'certainty (for everyone)' (A822/B850). Similarly, Kant also introduces a thought experiment involving betting as a way to distinguish 'mere persuasion' from 'subjective conviction', which he then identifies with 'firm belief' (A824/B852). Finally, he asserts that the conviction associated with our belief in God involves a 'moral certainty' that is distinct from the 'logical certainty' associated with knowledge and that, in contrast to knowledge, the contents of morally certain conviction are not communicable $(\mathrm{A} 829 / \mathrm{B} 857){ }^{7}$

One solution to this puzzle, of course, is to read the distinction between logical and moral conviction into Kant's previous discussions and insist that the former is at issue in the passages from A821/B849 and that the latter is at issue in the passages from A822/B850 and A824/B852. On this way of parsing the text, logical conviction would be communicable and universally valid, while the normative force of moral conviction would be more limited in scope. ${ }^{8}$ Yet as we will see, this approach reveals another tension. For Kant's discussion of pragmatic belief appears to suggest that at least some beliefs involve logical not moral conviction.

Another interpretative issue raised by our discussion so far is whether Kant can consistently claim that beliefs come in degrees. In his discussion of betting, he is quite clear that they do. Indeed, the point of this discussion is that the amount of money or other goods one is willing to wager on the truth of a proposition is an indication of how firmly one believes it. The problem, however, is that the kinds of considerations influencing the strength of one's bet are epistemic in nature - my understanding of the odds or of empirical facts related to the outcome, for example - and these considerations 
have no bearing on the non-epistemic warrants associated with belief. Consequently, as others have observed, Kant's discussion of betting threatens to reduce belief to opinion. ${ }^{9}$

With these issues in mind, there are two specific kinds of belief that are of particular interest to us: pragmatic and moral belief. ${ }^{10}$ A pragmatic belief is generally thought to be one that is warranted because it is a necessary condition for achieving a contingent end set by an agent. ${ }^{11}$ In Kant's example, a doctor who has set as his end the treatment of a patient whose ailment he subsequently discovers he cannot reliably diagnose must nonetheless assent to a claim ascribing a specific diagnosis to the patient in order to treat him, and this assent is warranted not on epistemic but pragmatic grounds.

While pragmatic belief concerns our contingent ends, moral belief concerns our necessary ones. In particular, a moral belief is a belief that is warranted as a necessary condition for realizing the 'absolutely necessary' end of satisfying 'the moral law in all points' (A828/B856). As Kant puts it, 'according to all my insight there is possible only a single condition under which this end is consistent with all ends together and thereby has practical validity, namely that there be a God and a future world' (ibid.). In contrast to the case of the doctor, then, moral beliefs are not subjectively but objectively necessary conditions for the achievement of the ends associated with them. It is not merely the case that I can think of no other means to the necessary end of satisfying the moral law 'in all points' but, rather, that I know 'with complete certainty' that no one else can think of an alternative means (A828/B857).

Consider now the relationship between moral belief and conviction. In the first Critique, Kant insists that our belief in God, the paradigmatic example of moral belief, carries with 
it only moral not logical conviction (A829/B857). Moreover, the primary lesson Kant draws from this claim is that we must take great care in articulating the nature of our belief in God, lest we misrepresent our epistemic position. We cannot say, 'It is morally certain that there is a God', but only that 'I am morally certain' that there is one (A829/B857). Crucially, Kant is also clear that belief is dependent on the presence of a moral disposition in the believer (ibid.). As a result, the conviction associated with moral belief must also be qualified. If it can be communicated, then only to those who possess a moral disposition; and while this is presumably a larger group than those who set any given contingent end, it still falls short of the universal validity of logical conviction.

Consequently, while Kant only draws a distinction between logical and moral conviction, there are at least two grades of moral conviction to consider. While both fall short of the communicability and universal validity of logical conviction, it is less clear where they stand in relation to each other. On the plausible assumption that there are more people with moral dispositions than who have adopted the same pragmatic-belief-dependent contingent end, it would appear that the scope of pragmatic belief is more restricted than that of moral belief. However, this claim is nowhere made explicit in Kant's text. For our purposes, however, we do not need to resolve this issue since we have now developed Kant's account of belief in sufficient detail to identify its antecedents in the work of Crusius, Meier, and Basedow.

\section{Crusius's Non-evidentialism}

Nearly forty years before the publication of the first Critique, Crusius published a detailed account of belief that is a clear antecedent to Kant's. Like Kant, he argues that some beliefs have non-epistemic warrants. Like Kant, he believes that these warrants 
arise from the relationship between beliefs and the ends we have as agents. And like Kant, Crusius refers to these beliefs as 'rational beliefs'. ${ }^{12}$ Crusius introduces this account in his Instruction for Living Rationally (1744) and develops it in important ways in his Path to Certainty and Reliability in Human Cognition (1747). ${ }^{13}$

In both works, Crusius recognizes a broad and a narrow sense of belief, neither of which is a perfect fit to Kant's. ${ }^{14}$ In the former, belief is identical to assent, making it much broader than Kantian belief. As Crusius puts it, belief in this sense is 'contrasted with doubt and negation' and means 'assent to a proposition' or 'accepting it as true' (ILR, §334). ${ }^{15}$ Further, belief underwrites action and checks further speculation. In particular, it consists 'in that condition of a rational spirit' in which (a) 'its will decides to regard a represented proposition as true and, to the extent this is not hindered by other causes, to act in accordance with the proposition when given the opportunity' and in which (b) 'the will does not drive the understanding to seek further proof either at all or at least not with the intention that it will not yet concede or act according to the proposition, in the event that no further proof can be found' (ibid.). In the narrow sense, however, Crusian belief is still broader than its Kantian counterpart. For in this sense, 'belief' designates any assent that falls short of the certainty associated with knowledge or, as Crusius puts it, 'the kind of conviction that cannot be further doubted once it is posited' (ibid.). In the narrow sense, then, Crusian belief includes both Kantian belief and opinion.

Regardless of which sense of belief is at issue, Crusius is also explicit that belief is not assent to a proposition 'on the basis of testimony’ (ILR, §334). Although Crusius does not make this explicit, the view he targets here is Wolff's, who construes belief as 'the assent one gives a proposition in virtue of the testimony of another' ${ }^{16}$ In contrast, Crusius 
argues that this construal of belief fails to accommodate either the broad or the narrow sense of the term. It cannot accommodate the former because it implies absurdly that there are no forms of assent besides testimony, and it cannot accommodate the latter because 'it is uncontroversial that one can believe one's own dreams and other irrational flights of fancy, even when they are not grounded on demonstration or testimony' (ibid.). Finally, Crusius argues that it would be of no help to modify the Wolffian position and say that belief involves assent to one's own testimony 'because our own testimony, if one wants to refrain from taking the words in an improper sense, is no testimony at all' (ibid.).

Within this general account of belief, Crusius recognizes several forms of what he calls 'rational assent', two of which bear a striking resemblance to Kantian pragmatic and moral belief (ILR, §340). ${ }^{17}$ Both involve non-evidentialist justification. For Crusius deems them rational not because the truth of the propositions in question is certain or even probable, but because assent to the propositions is a necessary condition of achieving a certain end. Regarding the first, Crusius writes that we may have 'proposed a certain end to ourselves whose nature entails that under certain conditions we must absolutely presuppose the truth of certain propositions ... since we would otherwise lose all assurance in our final end and all steadfastness in our pursuit of it' (ILR, §339). As an example, he claims that the end of having an intimate friendship requires that we "believe and trust' our friend 'in many instances without a particular proof' or else 'abandon the end of friendship' (ibid.). ${ }^{18}$

The second kind of rational assent concerns the more limited case of our duties to God. Here, Crusius claims that assent to a proposition is rational if it would otherwise be 
impossible to satisfy one of our duties to God. As he puts it: "Any time we would act contrary to an obligation to God by denying or not acting in accord with a proposition, we are bound to honour God by accepting the proposition with complete assent, confidently acting in accordance with it, and even by not paying attention to the doubts that may nonetheless remain’ (ILR, §345). Put somewhat differently, he writes: ‘One who is bound to a duty is also bound to avoid those things that would, in whole or part, deny and exclude that duty' (ibid.). ${ }^{19}$ Crusius's illustration of this kind of belief is that we have a duty to reject 'universal scepticism', even absent a demonstrative argument against it, because belief in it would 'negate all virtue and religion' and, hence, be a 'crime against God' $(I L R, \S 346) .^{20}$

Although he does not make this explicit, these two forms of rational assent are associated with two distinct forms of duty that Crusius discusses elsewhere in the Instruction. ${ }^{21}$ The first corresponds to a 'prudential duty' or one that rests on 'particular final ends antecedently desired by us', while the latter corresponds to a 'duty of virtue' or one that rests 'in a law and in our obligation to fulfil it' $(I L R, \S 162) .{ }^{22}$ More specifically, however, the law in question is a divine one, and the corresponding duty arises from what Crusius calls an 'obligation of virtue', which he describes as 'the relationship of an action or omission to a divine law, which entails that we will violate the law if we do not proceed in such and such a way' (ibid.).

In Path to Certainty, Crusius introduces these forms of belief as ones that depend on the 'connection a matter has with the particular ends of prudence or justice' $(P t C, \S 362) .{ }^{23}$ When he returns to these ideas in $\S 412$, Crusius then identifies two kinds of belief corresponding to those discussed in the Instruction. The first involves what he calls a 
'prudential obligation', which he defines as the 'moral necessity by means of which we must do or omit something if, to the extent we regard them as ours, we do not want to abandon our own final ends' $(P t C, \S 413)$. This form of obligation arises with respect to a proposition when 'accepting' and acting in accordance with it is either 'the only' or the most reliable means to attain 'certain human final ends' (PtC, §414).

The second kind of belief Crusius identifies involves what he calls 'lawful obligation', which he defines as 'the moral necessity in virtue of which we must do or omit something if we do not want to transgress the will of a supreme lord, on whom we depend and to whom we owe obedience' $(P t C, \S 413){ }^{24}$ This form of obligation arises 'when certain laws do not allow [us] to remain neutral in a case' and 'it would be somewhat possible, or even probable or certain, that one would transgress against these laws if one did not act according to the probable opinion and was not satisfied with having done so' (PtC, §415). Moreover, the degree to which we are obligated to believe the proposition grows with the importance of the law. Crusius continues: 'When therefore the duty arising from the law is a necessary one and the probability [of the proposition] as such is also great or even infinite, it is undeniable that the effect of the probability should be regarded as the same as [the effect] of what one cognizes through demonstration' (ibid.).

Crusius then proceeds to identify three sorts of lawful obligation. The first arises 'when action according to a certain probability is the only means to satisfy the law ... either as such or with respect to certain persons', the second 'when a probably cognized means to satisfy a duty is the surest among those that are available', and the third 'when the matter at issue in satisfying the duty is such that it already possesses as such a sufficient degree of probability or even a moral certainty’ (PtC, $\S 416$, my emphases). 
There are several points to observe. The first is that Crusius's conception of lawful obligation has expanded in Path to Certainty beyond a strictly religious context. For while all duties for Crusius issue ultimately from divine commands, his discussion now makes clear that lawful obligation can also arise with regard to duties that are not duties to God. ${ }^{25}$ Second, and relatedly, lawful obligation is now triggered in a broader array of circumstances than it was in Instruction. For while Crusius there insists that a lawful obligation warrants belief only if one would otherwise violate the obligation, he now allows that it warrants belief when the belief is merely the surest means to that end. Finally, while the third form of lawful obligation he identifies is simply the case in which one has a lawful obligation to believe a proposition that one would already believe on epistemic grounds, the first and second have clear affinities with Kantian pragmatic and moral belief. Since prudential obligation also shares many of these affinities, however, I begin with it.

There is a straightforward affinity between the belief justified by prudential obligation, which I henceforth refer to as prudential belief, and Kantian pragmatic belief. Both are justified on non-evidentialist grounds, and both are justified in virtue of the fact that the beliefs help us realize contingent ends. In contrast to Kant, however, who insists that in order to be warranted a belief must be necessary to achieve the end in question, the presence of a prudential obligation can justify a belief that is either (a) the only or (b) the most reliable means to realizing the end. Consequently, Crusian prudential obligation underwrites a far more permissive ethics of belief than Kant allows in the case of pragmatic belief. 
There is also a straightforward affinity between the belief justified by lawful obligation, which I henceforth refer to as lawful belief, and both pragmatic and moral belief. Crusius's insistence that a belief can be justified when it is the only means to satisfy a law 'either as such or with respect to certain persons' draws a distinction within lawful belief that is similar to Kant's distinction between moral and pragmatic belief ( $P t C$, $\S 416)$. For in Kant's discussion of the latter, he suggests that belief in a certain proposition can be a necessary means to an end for some but not all people (A824/B852). Similarly, Crusius's conception of lawful obligation captures the most distinctive aspect of Kantian moral belief, namely that the ends giving rise to the obligation and, hence, warranting the belief are necessary ones. For Crusius is clear that 'the execution of God's will and orders' should be our highest end and the one 'to which all other final ends and desires ... should be subordinated' (ILR, §176). Indeed, this last statement sounds very much like Kant's insistence that the moral law should be the limiting condition of all our other ends. And lest anyone suspect that Crusius believes the distinctively un-Kantian motives of fear of punishment and hope of reward are compatible with genuine moral action, he is clear that such motivations would 'negate all true lawful obligation and obedience' (ILR, §194). Thus, while Crusius obviously parts ways with Kant in regarding the moral law as dependent on God's will and, hence, on what Kant calls an 'external determining ground of the will', his position on what constitutes properly moral motivation is much closer to the Kantian view than one would expect (CPrR, 5:40). Like prudential beliefs, however, lawful beliefs are also far more permissive than their Kantian counterparts - as well as Crusius's first iteration of these beliefs - since all Crusius 
requires in Path to Certainty to justify assent is that a proposition be 'the surest' of those available to ensure that we do not violate our duties.

More importantly, however, while Crusius does not identify immortality or God as objects of lawful belief and, to this extent, stops short of anything like Kant's arguments for the postulates, his insistence in the Instruction that we have a lawful obligation to avoid scepticism is also an instance of what Kant will subsequently call a postulate of pure practical reason. Kant famously defines such a postulate in the second Critique as 'a theoretical proposition, though not one demonstrable as such, insofar as it is attached inseparably to an a priori unconditionally valid practical law' (CPrR, 5:122). As we have seen, Crusius holds that the rejection of 'universal scepticism', which is clearly a theoretical proposition, is necessary if we are to satisfy our obligations to God (ILR, §346). And while he does not specify in this section of Instruction that there is no demonstrative argument against this form of scepticism, it is clear that failing to reject it, even absent such an argument, would violate the trust we owe to God. In other words, this rejection is, as Kant puts it nearly fifty years after the publication of Instruction, 'attached inseparably to an a priori unconditionally valid practical law'.

\section{Crusius, Meier and 'Moral Arguments' for Immortality}

My goal in section 2 was to develop the non-evidentialist aspects of Crusius's account of belief and to highlight the similarities between them and Kant's account. In this section, I want to consider two related sets of arguments from the 1740s that scholars have recently suggested are important anticipations of Kant's moral argument for the first postulate and, by extension, his account of belief (see Dyck 2018, Rumore 2018). The first are drawn from Crusius, principally the Instruction, and the second from G. F. Meier's 
Thoughts on the State of the Soul after Death (1746) and his Defence of His Thoughts of the State of the Soul after Death (1748) ${ }^{26}$ As we will see, however, while there is a meaningful sense in which both Crusius and Meier develop moral arguments for belief in immortality, these arguments do not rely on non-epistemic warrants and, hence, fail to anticipate the most unique feature of their Kantian counterparts.

To begin, note that Crusius and Meier both reject demonstrative arguments for immortality and, moreover, that they do so for much the same reasons. ${ }^{27}$ Crusius asserts that the immortality of the soul cannot be demonstrable because immortality does not follow from the soul's essence (cf. ILR, §221 and Crusius 1745: §482). Similarly, Meier asserts that the soul's immortality is not demonstrable (a) because the 'mathematical certainty' entailed by demonstration would require insight into God's mind, which is unavailable to us, and - in a way reminiscent of Crusius - (b) because, as contingent beings, the non-existence of the soul and, hence, its annihilation at the moment of death are possible..$^{28}$

In addition, both Crusius and Meier also insist that the immortality of the soul is 'morally certain', that is, that it possesses the kind of certainty both associate with probability. For Crusius, a proposition is probable when it falls short of demonstration but requires us to assume less 'without demonstration' than its opposite (ILR, §338). In the more expansive discussion of probability in Path to Certainty, which as I have noted also includes the non-evidentialist forms of assent examined in section 2, Crusius writes that probability is 'the quality of a proposition by virtue of which one is inclined to hold it to be true, or at least is more inclined to hold it to be true than its opposite, regardless of the fact that its opposite can be thought' $(\operatorname{PtC}, \S 360)$. A proposition is then morally certain when it is 
'absolutely and incontrovertibly certain, despite the fact that its opposite can be thought' (PtC, §361). Similarly, a belief is probable for Meier when it falls short of demonstration and we 'cognize more or stronger grounds to accept it than to reject it' (Meier 1752b: §171; see also 1752a: §207). A probability is then morally certain when 'I know only grounds in favour of it, and not a single one against it except that I must admit that the opposite of the truth is possible' (Meier 1748: §67). ${ }^{29}$ Finally, both Crusius and Meier also articulate what are arguably 'moral arguments' for the soul's immortality. Indeed, Crusius is explicit that, absent demonstrative argument, 'moral grounds' are the only ones 'suited to proving the immortality of the soul' (ILR, §221).

As his subsequent arguments make clear, however, these grounds are not moral in Kant's sense. In the first place, their warrants are all epistemic in nature. Moreover, while one of Crusius's arguments does assert that immortality is a necessary condition of God's ability to justly reward and punish people in proportion to their precise degree of virtue and vice - a claim echoed by some of Kant's comments in the first Critique - there is nothing in any of Crusius's arguments like Kant's suggestion that belief in immortality is a necessary condition of our following the moral law 'in all points' (A824/B856). Rather, the sense in which the 'grounds' for belief in immortality are 'moral' for Crusius is that his arguments turn on claims about the free choice of God. Indeed, this is the primary sense of 'moral' for Crusius, who defines moralisch as whatever 'produces its effect by means of free will' (ILR, §161). ${ }^{30}$

While Crusius does not anticipate the distinctive moral nature of Kant's argument for immortality, Corey Dyck has suggested that Meier does. In particular, as Dyck reads Thoughts and Defence, Meier presents the salutary effects of belief in immortality on 
virtue and religion as non-epistemic warrants for belief in the immortality of the soul.

Further, he argues that while Meier's own account of doxastic attitudes does not include a category that captures the kind of assent Meier believes is warranted in the case of immortality, this form of assent is captured by Kant's account of belief. Thus, Dyck concludes that Meier 'constitutes a clear anticipation of Kant's own distinctive claim that the immortality of the soul is (merely) an object of a moral belief' (Dyck 2018: 77).

In contrast to Dyck, as I read the relevant passages of Thoughts and Defence, Meier's arguments are not moral in Kant's sense. In particular, while Meier does frequently note the salutary effects of belief in immortality on 'virtue and religion', I have found no instance in which he presents these effects as warrants for belief ( $T$, 88 ; cf. $\S \S 10$ and 12). Rather, it seems to me that what he does in these passages is emphasize that these effects are not undermined by his critique of the demonstrative arguments for immortality. And this in turn, I suggest, is motivated by his larger apologetic goal in the first part of Thoughts of forestalling the criticisms of "certain theologians who make a virtue of their exaggerated and blind religious zeal and take any pious thought for grounded' $(T, \S 3)$. When Meier claims, for example, that 'the immortality of the soul contains an excellent and important motivation for virtue and religion', he also emphasizes that 'since it is not necessary that our motives be mathematically certain, one can deny the certainty of the immortality of the soul through reason without weakening or extinguishing the zeal for virtue and piety' $(T, \S 12)$. Similarly, when he asserts that 'the immortality of the soul is one of the most important and excellent grounds of all virtue and religion', he also claims that undermining the demonstrative arguments for immortality will therefore allow us to 
'acknowledge the priority of Scripture to reason' and 'thank God that it so pleased his love of humanity to inspire us with a direct revelation' $(T, \S 8)$.

Moreover, when Meier refers to the 'many and important probable grounds' for the immortality of the soul, it seems to me that he is referring either to the evidence for this claim found in scripture and revelation he alludes to in the previous quotation or to the demonstrative arguments themselves $(T, \S 34) .{ }^{31}$ For while he insists that these arguments do not establish what they purport to, he also insists that many of them 'have elevated their conclusion to the highest degree of probability' $(T, \S 4)$. Indeed, it is for this very reason that Meier emphasizes he does not intend to 'overturn' these arguments 'entirely' but merely to deflate their claims of mathematical certainty (ibid.).

Thus, while Crusius's work contains antecedents both to Kant's distinction between practical and moral belief and to his conception of a postulate of pure practical reason, neither Crusius nor Meier develop arguments for the immortality of the soul that are moral in Kant's sense. Both deny that the soul's immortality is demonstrable and are, consequently, forced to develop probable arguments for it; but neither endorses belief in immortality on non-evidentialist grounds. There is, however, at least one German philosopher prior to Kant who does anticipate the most unique feature of his arguments for the postulates by claiming that there are non-evidentialist grounds for believing in both the immortality of the soul and the existence of God.

\section{Basedow on the 'Duty to Believe'}

Before founding Dessau's Philanthropinum in 1774, Basedow was a student of Crusius in Leipzig (1746-48) and later a professor of moral philosophy at the Danish 
Ritterakademie in Sorø (1753-61) and the Gymnasium Christianeum in Altona (1761-71), near his native Hamburg. ${ }^{32}$ Like Crusius, Basedow develops a non-evidentialist account of belief that predates Kant's. Like Crusius and Meier, he is critical of demonstrative arguments for the immortality of the soul (cf. Philalethie, §212). But unlike these philosophers and in anticipation of Kant, he extends this criticism to demonstrative arguments for the existence of God..$^{33}$ Most importantly, Basedow anticipates Kant in arguing that, despite these criticisms, belief in God and immortality is warranted on nonevidentialist grounds.

In his Theoretical System of Healthy Reason (1765), Basedow argues that there are two sorts of warrants for 'firm assent' to a proposition (TS III, §25). ${ }^{34}$ This discussion takes place within a chapter of the Theoretical System on the nature of truth that, in conjunction with a subsequent chapter on probability and instruction, constitutes Basedow's logic (cf. TS III, §24). The first of these is when 'reason is aware that all attempts to doubt [a proposition] are entirely in vain' and corresponds roughly to what Kant, Crusius and Meier regard as knowledge (ibid.). ${ }^{35}$ The second is when 'reason perceives [a] that it is inclined by nature to believe in such circumstances and [that] assent according to such rules is the most orderly means to achieve its ends and [b] that doubt would lead only to detours, where without usefulness only danger lies' (ibid.). Thus, like Crusius but unlike Kant and Meier, belief for Basedow can involve either epistemic or non-epistemic warrants.

While the reference in the previous quotation to reason's 'ends' might suggest that the second of these warrants corresponds roughly to belief for Kant and to the subsection of Crusian belief we examined in section 2, this second warrant also includes elements of 
what for Kant is opinion and for Crusius and Meier is probability. In particular, it includes 'undiminished general experiences', by which Basedow means experiences for which there are "many similar examples and either no exceptions at all or only those that are so little known that one should regard them as nothing when compared to the sum of the analogous experiences' as well as 'other propositions with regard to which [a practiced and reflecting reason] consistently perceives a duty to believe them' (TS III, §26). ${ }^{36}$ It is the former not the latter that have epistemic warrants.

In the context of elaborating on the latter, Basedow introduces his notion of a duty to believe (Glaubenspflicht). The core of this notion, which he discusses in other works as well, is that we have a duty to believe a proposition if (1) it is a practical proposition, i.e. one that could serve as the basis for action, (2) its truth is 'probable' in a fairly specific sense of that word, and (3) the consequences of doubting it, should it in fact be true, would be disadvantageous to us. ${ }^{37}$ As Basedow puts it: 'There are practical propositions that are probable to us in theory and remain only probable but which must be regarded as true in practice if we are not to act against important ends and put ourselves in danger' (TS III, §27). ${ }^{38}$

Put in this way, Basedow's view has something of a Pascalian or even Jamesian ring to it. However, there are several important differences. Regarding Pascal, Basedow's view is in the first instance much broader since the objects of the duty to believe can be anything that satisfies (1)-(3). Moreover, in his wager Pascal holds that 'reason can decide nothing', while Basedow insists that the proposition believed must at least be probable. ${ }^{39}$ Most importantly, while Pascal's argument is famously prudential, Basedow holds that the duty to believe is a genuinely moral one. Regarding James, while there is more 
agreement on the scope of potential non-evidential beliefs than between Pascal and Basedow, Basedow's view is still stricter insofar as he holds (a) that belief in the circumstances he describes is not merely permissible but obligatory and (b) that this obligation holds irrespective of whether the options are 'live' in James's sense (cf. James 1979: 717-34).

Since the notion of a practical proposition is already fairly clear, let us now consider what it means for a proposition to be probable for Basedow. A proposition is not probable when it is merely likely. Rather, it must either (c) have more evidence in its favour than 'any of the members of the complete disjunction of its opposite' or (d) agree better with our 'essential ends' than any of those disjuncts (TS III, §35). For Basedow, then, like Crusius in his later work, a proposition can be probable in virtue of either nonevidentialist or evidentialist warrants.

Thus there are two ways in which the probability of a proposition may combine with other factors and give rise to a duty to believe. If the proposition is deemed probable based on the evidence and is, in addition, practical and appropriately related to our 'important ends', a duty to believe arises, which obliges us to put our thumb on the scale, as it were, and enhance our commitment to the proposition beyond what the evidence warrants. In other words, if the epistemic merits of a proposition warrant something less than belief but warrant more than the epistemic merits of any of the alternatives, the relevance of belief in this proposition to our 'important ends' may constitute a nonepistemic merit that tips the scales in favour of belief. ${ }^{40}$ 
At the same time, however, Basedow's reference in his discussion of probability to our 'essential ends' makes clear that a proposition can be probable solely in virtue of its nonepistemic merits. For the relation of the proposition to these ends can be sufficient, according to Basedow, to make it probable and, in turn, to make it the kind of proposition with respect to which a duty to believe may arise. In this case, the proposition would, it seems, acquire additional non-epistemic merits that justify raising it to the status of belief. As we will see, it is ultimately this non-evidentialist sense of probability - which collapses the distinction between (2) and (3) above - that underlies Basedow's various appeals to the duty to believe.

Consider now the dangers of doubt and advantages of belief. First, as previously noted, Basedow's argument is not a prudential one. For the two foundational rules of duty he identifies are to 'act according to God's universal laws', which are designed to bring about the 'highest sum of happiness' for all, and to 'promote universal perfection' (TS III, $\S 23)$. Second, Basedow is ambivalent about the degree of advantage that can trigger a duty to believe. In the Theoretical System, these advantages are of almost Pascalian proportions. In the second edition of his Practical Philosophy for all Estates, however, Basedow writes that the 'universal rule' of the duty to believe is: 'you must want to believe, when you know that the doubt will harm you or put you in danger, and you must then endeavour to believe' (Basedow 1777: 270).

With all this in mind, I now turn to the role the duty to believe plays in Basedow's arguments for the existence of God and immortality of the soul. To begin, while he is critical of the Principle of Sufficient Reason, Basedow's argument for God's existence is, broadly speaking, a version of the cosmological argument (cf. TS IV, §§3-5). In 
particular, he argues that the impossibility of an endless regress of causes establishes the existence of a self-sufficient (selbstständig) being that is the cause of all other things (cf. $T S$, Preface, 18-19; III, $\S \S 1-4 ;$ IV, $\S 5)$. To show that this being is God, however, one must also show that it is the 'most rational, most powerful and most benevolent' being and also the 'author of all things' (TS IV, §1). In order to do this, one must appeal to the overall purposiveness of the world and the predominance of good over evil in it, both of which are established empirically (TS IV, §3).

Granting that these claims have been established, one is then able to conclude (e) that the self-sufficient being is intelligent and, hence, can be an author, as opposed to a mere cause, and (f) that its understanding, power and benevolence are greater than the sum of these qualities present in what the being has caused. However, these superlatives are not yet omni-predicates. For the qualities of the self-sufficient being can be greater than those of what it has caused without being infinitely greater, and it is here that the duty to believe first steps into the breach. Basedow writes: 'the duty to believe prohibits any rational person from setting limits to these properties [i.e. the understanding, power and benevolence of the self-sufficient being], even doing so as a mere supposition, for such a thought would not only be improbable but also disconsolate and thus displeasing to the self-sufficient being' (TS IV, $\S 5){ }^{41}$

To understand Basedow's reasoning, let us first specify the proposition:

$G$ A self-sufficient being exists that is omnipotent, omniscient omnibenevolent, and the author of all things. 
Basedow's language strongly suggests that he wants to prove that $G$ is probable in both the evidentialist and non-evidentialist sense. For in the previous quotation, he claims that the denial of $G$ would be both 'improbable' and 'disconsolate', and there would be no difference between these claims if the first were not implicitly a reference to the evidentialist sense of probability. However, there can be no evidentialist argument for $G$ since by Basedow's own admission the available evidence only demonstrates the existence of a merely superlative being. Thus we are left with the claim that $G$ is probable in the non-evidentialist sense, i.e. that $G$ agrees better with our 'essential ends' than any proposition contrary to it. If this could be shown, we would have a non-evidentialist warrant for $G$. The question then becomes: what are our 'essential ends' and how does $G$ relate to them? While Basedow is not explicit about what these ends are, the most likely candidates are the laws of morality. ${ }^{42}$ So his argument would be that we have a duty to believe $G$ because belief in $G$ is more conducive to moral action than any other proposition contrary to it.

Basedow's second appeal to the duty to believe concerns the existence of God as well, but it appears to be independent of his argument for the existence of the superlative selfsufficient being which, as we have just seen, his first appeal is meant to supplement. $\mathrm{He}$ writes:

As soon as one sees that doubt about the existence of God and his properties endangers the well-being of our soul and robs us of the purest pleasures and consolations, the proposition that God exist must, by virtue of the duty to believe, remain a morally and practically certain proposition, even if one cannot develop the proof himself or has forgotten it. (TS IV, §5) 
While Basedow again does not specify how doubting $G$ would endanger the well-being of our soul or what 'pleasures' and 'consolations' are associated with believing $G$, it is clear that he again has moral considerations in mind, which would make this argument an instance of the previous one.

The third appeal to the duty to believe is a justification for belief in the immortality of the soul. Echoing Crusius and Meier, Basedow first notes that there is no conclusive evidence of the soul's mortality. He then asserts that all people desire immortality once they understand the concept and that, given his previous argument for the predominance of good over evil in the world, immortality would likely be a pleasurable state. He then claims that God desires our immortality because he loves the existence of the beings he creates. Basedow then asserts, first, that it would be 'contrary to the duty to believe to think that the omnipotence of God would not be powerful enough to give the soul an unending life' and, second, that the 'confidence in our immortality ... is the strongest drive to virtue, which ordinarily at least makes our current life happier and whose violation would at least put us in the greatest danger if there should be a life after death, which is probable for so many reasons' (TS IV, §5). In other words, there is an obvious benefit in the here-and-now to belief in immortality, and there would be an additional benefit in the afterlife to this belief should it turn out that the soul is in fact immortal. ${ }^{43}$

Basedow's fourth and final appeal to the duty to believe is meant to justify our belief in a posthumous system of divine rewards and punishments. In particular, he claims that belief in such a system is a duty because 'God favours the world of spirits [Geisterwelt], sociability connected with virtue is an indispensable means to their happiness, and will 
also be so in the future life' and because 'rewards and punishment increase the sum of virtue and decrease or destroy vice' (TS IV, §5).

Although Basedow makes each of these appeals separately, his view is more plausible if we consider the collective effect of the beliefs in God, immortality and a posthumous system of divine rewards and punishments on what he calls our 'essential ends'. For what Basedow needs to show is that these beliefs agree better with these ends than any of their contraries, and this case is easier to make if we consider them as a corporate body. In a passage from the Practical Philosophy, Basedow discusses the instances in which virtue is the 'decisive cause of suffering that outweighs benefit' and vice the 'decisive cause of a state of pleasantness that outweighs disadvantage' (Basedow 1777: 79).

Acknowledging that these instances are impediments to virtue, he writes that this 'disharmony between the wishes of rational and far-seeing self-love and the true doctrine of virtue' can be 'entirely negated' if we consider the 'wisely benevolent divine providence and the truth that our souls are immortal and [that they] can only move forth eternally by increasing their wise love of lasting happiness' (ibid.). Collectively, then, belief in the existence of God, the immortality of the soul and a posthumous system of divine rewards and punishments removes a significant impediment to morality; and it is in this sense, I suggest, that Basedow thinks these beliefs agree better with our 'essential ends' than other propositions and are, therefore, appropriate objects of rational belief.

Such in brief are Basedow's arguments. While I hope to have shown that they have both substance and originality, my concern is primarily with their historical precedence and importance to Kant. Regarding the former, it should now be clear that Basedow's views are important antecedents to Kant's arguments for the postulates. For unlike Crusius's 
and Meier's moral arguments for immortality, Basedow's are non-evidentialist in nature; and unlike Pascal's argument for belief in God, Basedow's non-evidentialist grounds are moral rather than prudential. Regarding the latter, while the evidence of Kant's engagement with Basedow's philosophy is less voluminous than for his engagement with Crusius's and Meier's, it is enough to claim that Basedow's account of the duty to believe influenced the development of Kant's arguments.

In the first instance, Kant appears to have something like Basedow's view in mind in the second Critique when he claims that belief in God is a 'moral necessity' but not a 'duty' (CPrR, 5:126). More significantly, however, there are explicit references to the duty to believe in Kant's drafts of the introduction to the Doctrine of Right. There he contrasts 'juridical duties' which 'are grounded in an actual legislation' with 'duties to believe' for which 'the acceptance of an eternal legislator and the hypothesis of the same as such are made a duty to the benefit the exercise of an inner law' (DDR, 23: 267). He then continues by explicitly connecting the duty to believe to the doctrine of the highest good and the second postulate. In particular, he writes that duties to believe 'can only apply to the duty to promote the highest good, hence, to assume that the idea of the highest good has objective reality' and that this idea has objective reality 'only insofar as God is possible, which can only be thought insofar as one accepts a divine lawgiver of nature as well as freedom (DDR, 23: 278). Basedow's name is not mentioned in these passages. However, since the term Glaubenspflicht was closely associated with him, it strikes me as highly implausible that his views are not in the background of Kant's thought. ${ }^{44}$

\section{The Development of Kantian Belief}


Much of what has been written about Kant's account of belief and the postulates suggests that both sprang from his head, if not fully formed, then at least without the midwifery of his fellow philosophers. As we have seen, however, this impression is mistaken. Crusius develops a non-evidentialist account of belief in the 1740s that is a clear antecedent to the distinction Kant draws almost forty years later between pragmatic and moral belief, and Crusius's primary example of the latter is an antecedent to Kant's notion of a postulate of pure practical reason. To the extent that both of these are regarded as uniquely, even paradigmatically Kantian doctrines, our narrative of the development of non-evidentialist arguments for religious belief and the ethics of belief should be revised to acknowledge Crusius's contributions to the debate itself and Kant's place within it. ${ }^{45}$

Moreover, while I have argued that Crusius's and - pace Dyck - Meier's arguments for immortality fail to anticipate the most characteristic feature of their Kantian counterparts, they nevertheless represent a decisive break from the preceding German tradition of rational psychology insofar as they hold that the immortality of the soul can only be supported by probable arguments. Further, it is equally clear that this break is an important step in the direction of Kant's arguments. At the same time, however, we have also seen that it is not Kant but Basedow who first develops non-evidentialist arguments for belief in what Kant will subsequently call the first and second postulates. Moreover, since Basedow not only endorses Crusius and Meier's critique of demonstrative arguments for the immortality of the soul but also extends it to encompass demonstrative arguments for God's existence, his views and overall philosophical orientation are the closest to Kant's of the philosophers we have considered. 
While much of what is generally regarded as original to Kant can thus be found in the work of these figures, we have also seen that it would be a mistake to think that Kant does not modify their views in important ways. As we saw in section 2, for example, the bar Crusius sets for prudential and lawful belief is far lower than the bar Kant sets for pragmatic and moral belief. For in the case of the latter but not the former a belief is warranted only if it is a necessary means to an end, whether this end is itself necessary or contingent. Moreover, whatever the similarities between their accounts of moral motivation may be, Kant's insistence that rational agents are themselves the authors of the moral law is an enormously consequential rejection of previous meta-ethical views, including Crusius's voluntarism. Consequently, the nature of the moral obligations underlying Kantian moral and Crusian lawful belief could hardly be more different. Similarly, while Basedow's arguments are echoed by Kant's first Critique position that belief in God and immortality is necessary to make 'majestic ideas of morality ... incentives for resolve and realization' and not merely 'objects of approbation and admiration', they are quite unlike his mature position that belief in the postulates is required by our duty to promote the highest $\operatorname{good}(\mathrm{A} 813 / \mathrm{B} 841){ }^{46}$

In section 1, I limited myself to Kant's first Critique account of belief. I did this both to set aside the complex issue of how this account develops over time and because the first Critique is the place where the influence of the figures I have discussed is most apparent. Having examined this influence in some detail, we are now in a position to consider, albeit briefly, its impact on the development of Kant's views. As Pasternack has shown, there is a considerable narrowing of Kant's conception of belief in the period from the 'What is Orientation in Thinking' of 1786 to the third Critique of 1790 (Pasternack 2011: 
297-304). In the former, Kant abandons the idea that belief can be a matter of degree, assigning this quality to opinion (WOT, 8: 141). In the latter, he makes clear that the only suitable objects of belief are those that are 'inaccessible to theoretical cognition' and 'necessary to presuppose as a condition for the possibility of the highest moral final end' (CPJ, 5: 471).

In Kant's mature view, then, only moral belief is genuine belief, and the only legitimate objects of moral belief are the postulates. ${ }^{47}$ In other words, Kant abandons the idea that empirical propositions, such as ones concerning the disease afflicting a particular patient or the trustworthiness of a friend, can ever be justified on non-evidentialist grounds. And this is a rejection both of Kant's first Critique account of pragmatic belief and the Crusian account of prudential belief I have suggested was its model. Moreover, despite the fact that all of Basedow's appeals to the duty to believe concern propositions whose truth is, from Kant's perspective, 'inaccessible to theoretical cognition', the narrowing of Kant's conception of belief is a rejection of at least the scope of Basedow's view as well. For there is nothing in his account of the duty to believe that restricts these duties to nonempirical subject matter. Moreover, Kant's insistence that adopting the attitude of belief is warranted only if it is a necessary condition 'for the possibility of the highest final end' sets a much higher bar for the non-epistemic warrant than either Crusius or Basedow. Having already addressed this point with regard to Crusius, I now note only that, as we saw in section 4, Basedow's Practical Philosophy is quite liberal about the degree of advantage that can trigger a duty to believe. Indeed, there is nothing in the structure of that account, in contrast to the examples he gives, that would exclude Kantian pragmatic belief. Thus, while our examination of Kant's first Critique account of belief reveals a 
considerable debt to Crusius and Basedow, the final position he stakes out from the second Critique onwards is a distinctively Kantian departure from both. ${ }^{48}$

\section{Notes}

${ }^{1}$ Pasternack 2011, Guyer 2016, Dyck 2018 and Rumore 2018 are exceptions. As will become clear in section 3, however, Dyck overstates Meier's importance to Kant. The scope of this essay prevents me from addressing Pasternack's discussion of Meier directly. However, the argument of section 2 suggests that he overstates this importance as well. My overall interpretation of Crusius is consistent with Rumore's but more expansive in scope, insofar as I address both Crusius's account of belief and his views on immortality. Finally, Guyer's assertion that Mendelssohn's Phädon is an important source for Kant is tenuous, in part because, as Guyer himself notes, the argument he discusses actually presupposes the soul's immortality. While it appeared too late for me to consider, Gava 2019 also deserves mention in this regard.

2 'Holding-to-be-true' is the literal translation of the German term Fürwahrhaltung, which was used broadly (if not always consistently) in the eighteenth century to refer to all forms of doxastic attitudes. For simplicity, however, I will generally use 'assent' and its cognates.

${ }^{3}$ I cite Kant's works in the standard way from the first Critique ('A/B') and from Kant (1900 -), and use the translations in Kant $(1996,1999,2000)$. All other translations are my own.

${ }^{4}$ As we will see in sections 2 and 3, Kantian opinion is closest to what both Crusius and Meier call probability (Wahrscheinlichkeit). The subject matter of opinion is empirical and bears some connection to something that is known. Otherwise, it reduces to 'arbitrary 
invention' or a 'game of imagination' (A823/B851). Hence, the subjective insufficiency of belief does not imply that the assent is unjustified. See Pasternack 2014 for more discussion.

${ }^{5}$ While the figures I discuss typically refer to grounds (Gründe), I will often render their views in the more contemporary idiom of warrants. Doing so carries no philosophical weight.

${ }^{6}$ Pasternack (2014: 47n13) faults both Chignell (2007a) and Stevenson (2003) for not modelling conviction in a way that includes belief. It seems to me, however, that there is less distance between Pasternack and these scholars on this issue than he grants. Stevenson (2003: 85) approvingly cites Wood's claim (1970: 14) that both belief and knowledge involve conviction. Similarly, Chignell (2007b: 59n4) notes the ambiguity in Kant's use of Überzeugung, claims that Kant is working with two notions of conviction (one logical and the other practical) and stipulates that he will use 'conviction' as shorthand for 'logical conviction' in the remainder of the article. Chignell 2007a does not make a similar stipulation, but his discussion of conviction (2007a: 355) suggests that, implicitly at least, 'conviction' is shorthand for 'logical conviction' there as well.

${ }^{7}$ Since Kant writes that the conviction associated with moral belief 'is' moral certainty, I use the terms 'moral conviction' and 'logical conviction' in what follows. While I do this largely for convenience, there is precedent at CPJ, 5: 463, and JL, 9: 72.

${ }^{8}$ Pasternak (2011: 307-15) also suggests that the communicability of at least some kinds of belief is less than that associated with logical conviction.

${ }^{9}$ See Chignell 2007a: 339 and 341n20; Pasternack 2011: 300n30; and Stevenson 2003: 93-4. 
${ }^{10}$ Kant also briefly discusses a third form of belief that he refers to as 'doctrinal belief', which he describes as 'unstable' (A827/B855). Since it is also not discussed in his subsequent works, I ignore it here. See Pasternack 2010 for further discussion.

${ }^{11}$ My own view is that Kant actually defines pragmatic belief more narrowly than this to include only beliefs that are necessary means for the realization of a given end for all agents who might adopt that end and that the beliefs that are necessary for the realization of a given end for some agent or another are what Kant at A824/B852 refers to as 'contingent beliefs'. In this brief overview, however, I adopt the characterization generally found in the literature.

${ }^{12}$ For example, the title of the chapter in ILR (see next note) that addresses these issues is 'On rational belief as a duty toward God with respect to the understanding and will at the same time'.

${ }^{13}$ Kant's knowledge of these works - cited as $I L R$ and $P t C$, respectively - is well documented. Apart from Crusius's reputation and the fact that he was a mentor to Kant's teacher Martin Knutzen, Kant owned a copy of the second edition of ILR as well as a work referred to as 'Crusii Logica' by the company that auctioned off his books upon his death. See Warda 1922: 47. While the date of this work does not correspond to the date of $P t C$, it is likely that this is the text to which 'Crussii Logica' refers. Should this not be the case, however, and the reference be, as Warda suggests, to an unknown book about Crusius's logic, references to Crusius's logic at L-Log, 24: 38, 82, 316, 335 468, 613, 701, 796; and JL, 9: 21 all attest to Kant's familiarity with this work.

${ }^{14}$ Compare the discussion to follow, drawn from $I L R$, to $P t C, \S 447$. 
15 The term I here translate as 'assent' is Beifall, which Crusius tends to use interchangeably with Fürwahrhalten. Compare the gloss of ILR, §335 with the first sentence of the section itself. See also PtC, $\S 444$.

${ }^{16}$ Wolff 2004: ch. 7, §3. Wolff's term for 'assent' here is Beifall as well.

${ }^{17}$ Crusius's term here is vernunfmässiges Beifall. The remaining kinds of rational assent Crusius discusses are demonstration and probability. I return to the ILR's discussion of probability in section 3. For the moment, my focus is on the non-evidentialist forms of belief he recognizes.

${ }^{18}$ For a contemporary exploration of this example, see Stroud 2006.

${ }^{19}$ To 'deny' a duty in this case is, I take it, to act in a way that implies one does not have it. Similarly, to 'exclude' a duty is to act in a way that is per se contrary to it. Since actions here include beliefs, I might fail to avoid things that deny my duty of care to my son by believing I do not need to pick him up from his day care at a reasonable time. Similarly, I might fail to avoid things that exclude this duty by regularly having late afternoon meetings with students.

${ }^{20}$ Crusius notes that belief in universal scepticism is also contrary to the trust owed God since it would imply that God has made our reason such that 'it is incapable of presenting us with any truth'.

${ }^{21}$ The ILR is Crusius's main work of practical philosophy, and it includes a long portion on ethics immediately preceding the portion of the book entitled 'Natural Moral Theology' from which the majority of my quotations from the ILR are taken.

${ }^{22}$ Crusius's use of 'final end' is somewhat misleading to Kantian ears since a final end is often, as in this case, what Kant would simply call an end. 
${ }^{23}$ There is an important change in Crusius's understanding of probability from ILR to $P t C$. In the former, Crusius is clear that the beliefs we have been discussing are distinct from both knowledge and probability (cf. $I L R, \S 339$ ). In $P t C$, however, Crusius defines probability in a way that includes them within its scope. Importantly, however, in emphasizing that these beliefs depend on the "connection a matter has with the particular ends of prudence or justice', Crusius means to distinguish them from probabilities that depend 'only on the understanding' (PtC, §362). As a result, in PtC but not ILR, probability is meant to include some non-epistemic warrants.

${ }^{24}$ Crusius also includes a cross reference to $I L R, \S 162$ in which, as we have seen, he discusses 'obligations of virtue'. As he makes clear in that section, these are identical to the 'lawful obligations' he is now discussing.

${ }^{25}$ In ILR, $\$ 317$ Crusius asserts that 'all duties of virtue are duties to [gegen] God' and that 'all lawful obligation is grounded in God's will'. However, he then distinguishes between immediate and mediate duties to God, the latter of which are those that have 'God as the immediate object'. Technically speaking, then, what is made clear in PtC is that lawful obligation can arise with regard to duties that are not immediate duties to God. ${ }^{26}$ I cite Meier's Thoughts as $T$ in what follows.

${ }^{27}$ In this context, demonstrative arguments are ones whose conclusions cannot be denied without contradiction and that underwrite claims of knowledge as opposed to probability, opinion or belief.

${ }^{28}$ Cf. $T$, §5. Dyck 2018: 77-82 and Rumore 2018: 216-9 discuss these arguments in more detail. 
${ }^{29}$ See Meier 1752b: $§ 175$ and Meier 1752a: $\$ 207$ for Meier’s subsequent characterizations of moral certainty.

${ }^{30}$ For discussion of these arguments, see Rumore 2018: 219-25.

${ }^{31}$ In the context of this passage, it is clear that the grounds Meier refers to are all based 'on the light of reason'. However, he includes revelation in discussion of these issues in $T, \S 8$.

${ }^{32}$ Kant extolls the virtues of this school in his 'Essays Concerning the Philanthropinum', and Basedow makes his debt to Crusius clear in $\$ 213$ of his Philalethie (1764).

${ }^{33}$ I cite this work as TS in what follows. See Philalethie, vol. $2 \S \S 155,181,183,185$ and 189. Crusius was also critical of the ontological argument, and Basedow follows him in this regard.

${ }^{34}$ Basedow's term is feststehender Beifall. The pagination of this work, which is the first in which Basedow uses Glaubenspflicht, makes it challenging to cite. With the exception of two prefatory sections - the 'Preface' and an annotated table of contents that Basedow labels the 'Systematic Order and Academic use of this Book' - which have a continuous pagination, I cite the $T S$ according to book and section number, using Roman numerals for the former and Arabic for the latter.

${ }^{35}$ Basedow uses 'knowledge' (Wissen) and 'belief' less consistently than these figures. In the $T S$, he writes that knowledge is 'belief or acceptance of principles, one's own experiences, and of the consequences of a demonstration' and that belief is 'knowledge on the basis of testimony or instruction' (TS III, §37). In his discussion of this material in the second edition of his Practical Philosophy for all Estates, he is more circumspect. There he writes that knowledge is the form of assent we give 'our carefully made sensible 
perceptions ... what we perceive internally of ourselves ... first principles and ... their consequences' and that belief is the form of assent we give a proposition in virtue of 'the power of experience ... aggregated probabilities ... and instruction and testimony' (Basedow 1777: vol. 2, 265).

${ }^{36}$ Basedow also recognizes a third kind of assent that rests on the second kind of ground, namely the 'proper [logical] consequences' of the first two kinds of propositions (TS III, $\S 26)$.

${ }^{37}$ The term Glaubenspflicht first appears in the TS. However, Basedow explores related ideas in the first edition of his Practical Philosophy and in his Philalethie. As Basedow makes clear, however, the TS largely supersedes the latter (Cf. TS, 'Systematic Order', 25). The discussion of Glaubenspflicht in the second edition of the Practical Philosophy agrees with the presentation in the $T S$ and is also largely identical to the version in both editions of his Elementarwerk. The term also appears in his Methodenbuch, which was the textbook for Kant's WS 1776-7 lectures on pedagogy. While examining the development of Basedow's views across these works is a worthy task, it is also beyond the scope of this article.

${ }^{38} \mathrm{Cf}$. TS, Preface, 5 where he also uses the term Glaubenspflicht.

${ }^{39}$ Pascal 1991: §233. For recent discussion, see Jordan 2006.

${ }^{40}$ I borrow the term 'epistemic merit' from Chignell 2007a: 333.

${ }^{41}$ The self-sufficient being here functions as a moral exemplar not as a force to be feared. At this point in the argument, Basedow believes he has proven that this being exists and that it is the most benevolent being known to exist. If such a being would be displeased by an action, one would thus have a strong prima facie reason not to perform it. In this 
case, it is the consolation (Trost) lost by not believing in an infinitely powerful, knowledgeable and benevolent being, which we do not know to exist, that would be displeasing (missfällig) to the merely most powerful, knowledgeable and benevolent being, which we do know to exist.

${ }^{42}$ In Basedow 1777: 79, for example, he claims that the highest law is to 'be virtuous'.

${ }^{43}$ This last claim is a Pascalian coda to Basedow's otherwise non-prudential argument. In some his earlier work, Basedow's views are more Pascalian. See Basedow 1758: 673. ${ }^{44}$ See, for example, Mendelssohn 2011: ch. 8, which Beiser (1987: 97) takes to be a veiled reference to Kant's doctrine of the postulates. Kant was keenly aware of Mendelssohn's text since it is part of the nexus of views he responds to in the 'Orientation Essay'.

${ }^{45}$ Recent overviews of this material that make no mention of Crusius include Marušić 2011 and Chignell 2018.

${ }^{46}$ For further discussion of this shift, see Chance and Pasternack 2018.

47 This includes the postulate of freedom, which I have set aside for the purposes of this essay. For an account of why Kant does not include freedom in the first Critique's discussion of belief, see Rauscher 2010: 303-4.

${ }^{48}$ I am grateful to Lawrence Pasternack for discussion and to two anonymous referees for helpful comments on previous versions of this paper.

\section{References}

Basedow, J. N. (1758) Praktische Philosophie für alle Stände. Copenhagen and Leipzig: Johann Benjamin Ackermann. (1764) Philalethie. Altona: David Iversen. 
------- (1765) Theoretisches System der gesunden Vernunft. Altona: David Iversen.

-------(1777) Praktische Philosophie für alle Stände, $2^{\text {nd }}$ ed. Dessau and Leipzig:

Siegfried Lebrecht.

Beiser, F. (1987) Fate of Reason: German Philosophy from Kant to Fichte. Cambridge: Harvard University Press.

Chance B. and L. Pasternack (2018) 'Rational Faith and the Pantheism Controversy: Kant's 'Orientation' Essay and the Evolution of his Moral Argument'. In Daniel Dahlstrom (ed.), Kant and his German Contemporaries: Aesthetics, History, Politics, and Religion (New York: Cambridge University Press), pp. 195-214.

Chignell, A. (2007a) 'Belief in Kant'. Philosophical Review, 116, 323-60.

------- (2007b) ‘Kant’s Concepts of Justification'. Noûs, 41, 33-63. - (Spring 2018) 'The Ethics of Belief'. In E. Zalta (ed.), Stanford Encyclopedia of Philosophy, viewed 21 March 2019, $<$ https://plato.stanford.edu/archives/spr2018/entries/ethics-belief/>.

Crusius, C. A. (1744) Anweisung vernüftig zu leben. Leipzig: Gleditsh.

------- (1745) Entwurf der notwendigen Vernunftwahrheiten. Leipzig: Gleditsh.

------- (1747) Weg zur Gewissheit und Zuverläßigkeit der menschlichen Erkenntnis. Leipzig: Gleditsh.

Dyck, C. (2018) 'G. F. Meier and Kant on the Belief in the Immortality of the Soul'. In C. Dyck and F. Wunderlich (eds), Kant and His German Contemporaries: Logic, Mind, Epistemology, Science and Ethics (New York: Cambridge University Press), pp. 76-93. 
Gava, Gabriele (2019) 'Kant and Crusius on Belief and Practical Justification'. Kantian Review, 24, 53-75.

Guyer, P. (2016) 'Kant, Mendelssohn, and Immortality’. In T. Höwig (ed.), The Highest Good in Kant's Philosophy (Berlin: De Gruyter), pp. 157-179.

James, W. (1977) 'The Will to Believe'. In J. McDermott (ed.), The Writings of William James: A Comprehensive Edition (Chicago: University of Chicago Press), pp. $717-734$.

Jordan, J. (2006) Pascal's Wager: Pragmatic Arguments and Belief in God. Oxford: Oxford University Press.

Kant, I. (1900 -) Gesammelte Schriften. Ed. Royal Prussian (later German, then BerlinBrandenburg) Academy of the Sciences. Berlin: George Reimer (later Walter de Gruyter).

------- (1996) Practical Philosophy. Ed. and trans. M. J. Gregor. New York: Cambridge University Press.

------- (1999) Critique of Pure Reason. Ed. and trans. P. Guyer and A. Wood. New York: Cambridge University Press. - (2000) Critique of the Power of Judgment. Ed. P. Guyer, trans. P. Guyer and E. Matthews. New York: Cambridge University Press, 2000.

Marušić, B. (2011) 'Ethics of Belief’. Philosophy Compass, 6, 33-43.

Meier, G. F. (1746) Gedanken vom Zustande der Seele nach dem Tode. Halle: Hemmerde.

------- (1748) Vertheidigung seiner Gedanken vom Zustande der Seele nach dem Tode. Halle: Hemmerde. 
------- (1752a) Vernunftlehre. Halle: Gebauer.

------- (1752b) Auszug aus der Vernunftlehre Halle: Gebauer.

Mendelssohn, M. (2011) Morning Hours. Ed. and trans. D. Dahlstrom and C. Dyck.

Dortrecht: Springer.

Pascal, B. (1991) Pensées. Ed. P. Sellier. Paris: Bords.

Pasternack, L. (2010) 'Kant's Doctrinal Belief in God'. In O. Thorndike (ed.), Rethinking Kant, vol. 3 (Newcastle: Cambridge Scholars Press), pp. 200-18.

------- (2011) 'The Development and Scope of Kantian Belief: The Highest Good, the Practical Postulates, and the Fact of Reason'. Kant-Studien, 102, 290-315.

------- (2014) 'Kant on Opinion: Assent, Hypothesis, and the Norms of General Applied Logic'. Kant-Studien, 105, 41-82.

Rauscher, F. (2010) 'The Appendix to the Dialectic and the Canon of Pure Reason: The Positive Role of Reason'. In P. Guyer (ed.) Cambridge Companion to Kant's ‘Critique of Pure Reason' (New York: Cambridge University Press), pp. 290-309.

Rumore, P. (2018) 'Kant and Crusius on the Role of Immortality in Morality'. In C. Dyck and F. Wunderlich (eds), Kant and His German Contemporaries: Logic, Mind, Epistemology, Science and Ethics (New York: Cambridge University Press), pp. 213-31.

Stevenson, L. (2003) 'Opinion, Belief or Faith, and Knowledge'. Kantian Review, 7, 72101.

Stroud, S. (2006) ‘Epistemic Partiality and Friendship'. Ethics, 161, 498-524.

Warda, A. (1922) Immanuel Kants Bücher. Berlin: Martin Breslauer. 
Wolff, C. (2004) Vernüftige Gedanken von den Kräften des menschlichen Verstandes und ihrem richtigen Gebrauch in Erkenntnis der Wahrheit. Hildesheim: Georg Olms.

Wood, A. (1970) Kant's Moral Religion. Ithaca: Cornell University Press. 